Croatia

\title{
Irish Women's Fiction of the Twentieth Century: The Importance of Being Catholic
}

\begin{abstract}
Summary
This paper explores the ways in which some of the best and most representative Irish women fiction writers of the twentieth century responded to the exigencies of Catholicism in their selected works. It also attempts to demonstrate how the treatment of Catholicism in Irish women's fiction changed throughout the century. The body of texts that are examined in the paper span almost seventy years, from the early years of the independent Irish state to the turn-of-the-century Ireland, during which time both Irish society and the Irish Catholic Church underwent fundamental changes. How these authors tackle the relationship between the dominant religion and the shaping of woman's identity, how they see the role of woman within the confines of Irish Catholicism, and to what extent their novels mirror the period in which they are written are the main issues which lie in the focus of the paper.
\end{abstract}

Key words: Irish women's fiction, Catholicism, censorship, religious ideology, authority

\section{Leposlovje izpod peres irskih pisateljic dvajsetega stoletja: Pomembno je biti katolik}

Povzetek

Prispevek obravnava, kako so se nekatere najboljše in najvidnejše irske pisateljice dvajsetega stoletja v svojih delih odzivale na zahteve katolištva. Predstavi tudi, kako se je pristop h katolištvu v delih irskih avtoric spreminjal skozi čas. Izbor analiziranih besedil obsega skoraj sedem desetletij od zgodnjih let Svobodne irske države do Irske na prelomu stoletja, torej obdobje, v katerem sta se irska družba in irska katoliška cerkev bistveno spremenili. Članek se osredinja na pristop avtoric do odnosa med dominantno religijo in oblikovanjem ženske identitete ter na vlogo ženske v okviru omejitev irskega katolišstva. Prispevek ugotavlja tudi, v kolikšni meri proučevani romani odsevajo obdobje, v katerem so bili napisani.

Ključne besede: leposlovje irskih pisateljic, katolištvo, cenzura, verska ideologija, avtoriteta 


\section{Irish Women's Fiction of the Twentieth Century: The Importance of Being Catholic}

\section{Introduction: Irish Catholicism and Censorship}

Until the last decades of the twentieth century, Catholicism as a way of living, thinking and behaving was deeply ingrained in Irish society. More often than not the terms "Irish" and "Catholic" seemed naturally intertwined. The tacit "marriage" between Church and State resulted in the huge impact the former exerted on the latter in virtually every matter, from the beginning of the fragile Irish statehood. Catholic moral doctrines, especially those related to the family, divorce and contraception but also those related to censorship and education, were finally incorporated into Irish legislation when the 1937 Irish Constitution came into force. The highly controversial constitution might be said to graphically illustrate philosopher Louis Althusser's remarks on how individuals are subjected to certain ideological forces he terms "ideological state apparatuses." In his famous 1969 essay, "Ideology and Ideological State Apparatuses", Althusser examines the function and influence of social forces such as religion, school, family, the political system, and censorship, to name a few, which continually control the everyday lives of individuals. According to him, they function both by ideology and by repression. Althusser's view on the repressive aspect of these apparatuses is especially significant if we have the Irish context in mind: "Schools and Churches use suitable methods of punishment, expulsion, selection, etc., to 'discipline' not only shepherds, but also their flocks. The same is true of the Family ... The same is true of the cultural ISA Apparatus (censorship, among other things), etc." (2006, 98). Observed in the light of his thesis, the Irish were deeply "steeped in," that is, subjected to the ideology of the Irish Catholic Church. Unsurprisingly, it completely permeated not only education and family, but also the political and cultural state apparatuses for most of the twentieth century. In other words, religious ideology consistently hailed the Irish as subjects.

It is therefore virtually impossible to discuss twentieth century Irish literature without mentioning the rigorous censorship apparatus set up in the twenties. In the Irish context, literary censorship was eagerly enacted under the patronage of both Church and State. Louise Fuller stresses how it was "expressively designed to protect Irish Catholics from secularist or corrupting influences emanating from abroad." Anything that members of censorship boards considered even a minor threat to public morality had to be officially proscribed $(2002,37)$. As Marjorie Howes remarks, the initial draft of the Censorship of Publications Act, "equated sexual passion with sexual immorality" $(2002,928)$. In this light, it is not surprising that even the slightest reference to sex or any kind of "immoral" conduct in a book was to be condemned and proscribed. Julia Carlson reasonably argues in her book Banned in Ireland that the apparatus of censorship kept the Irish in total ignorance not only of intellectual and artistic developments in their own country and abroad but of sexual matters, as well $(1990,12)$. Lee Dunne, whose novel The Cabfather was the last novel banned in Ireland (as late as 1976), thinks that what lay behind Irish censorship was "shame, shame relating to sex, guilt relating to sex, fear relating to sex" $(1990,89)$.

It should be noted that reviewers had publicly dismissed books even before the official foundation of The Censorship Board in 1929, always relentlessly invoking Catholic values. A negative review of James Joyce's Ulysses (funnily enough, never officially forbidden in Ireland, although it was banned in Great Britain and in the United States) $)^{1}$ might serve as a perfect paradigm of a

Ulysses was unbanned in the United States in 1934 after the court ruled that it was "not pornographic." However, this was not 
censorship mentality in the young Free State. Dublin Review assessed the novel in September 1922 and demanded "destruction or, at least, its removal from Catholic houses" as "in it lies not only the description but the commission of sin against the Holy Ghost" (Cairns and Richards 1988, 134). In the decades to follow, many remarkable books were banned and had to be taken out of "good Catholic houses," and many of the best writers driven into Joycean exile. The banned writers, as Julia Carlson suggests, were all "tagged as nasty, indecent and immoral" (1990, 2). John McGahern was thus fired from a teaching post in a primary school after his novel The Dark was banned in 1965 and, consequently, he could not get any job in Ireland. He went to London, where he stayed for several years, and then returned to Ireland. Irish moralists accused Edna O'Brien, on the other hand, of having offended both the Catholic Church and Irish women with her early work, The Country Girls Trilogy. She was stigmatized as a "smear on Irish womanhood" (1990, 76). Her enraged local community went as far as to burn "heretic" copies of her books in "the chapel grounds" $(1990,72)$. Needless to say, O’Brien was soon forced to leave Ireland and go to live in self-imposed exile in London, where she has lived ever since. As Cairns and Richards comment and, as we will see also in the case of another banned writer, Kate O'Brien, ${ }^{2}$ for a long time throughout the last century, "exile seemed to offer the only space in which critical thinking on Ireland and its identity could occur" $(1988,134)$.

This paper will therefore attempt to examine how Althusser's ideological apparatuses of religion and censorship influenced Irish literature, especially Irish women's fiction throughout the last century. How some of the best women authors of the twentieth century tackle the relationship between the dominant religion and the shaping of woman's identity, how they see the role of woman within Catholicism, and finally, to what extent they question and criticize the Catholic Church are the key issues which lie in the focus of the paper. Their selected novels span almost seventy years, from the early years of the independent Irish state to the turn-of-the-century Ireland, during which time both Irish society and the Irish Catholic Church underwent fundamental changes. The paper will also attempt to demonstrate how the treatment of Catholicism in these works changed throughout the century.

\section{Kate O'Brien and how the Censorship Board (re)acted in the thirties and forties}

The above mentioned constant shame, guilt and fear relating to sex and sexuality in general is perhaps best reflected in the banning of Kate O'Brien's 1941 novel The Land of Spices, which is set entirely in the enclosed space of an Irish convent school. Irish journalist Brian Fallon bluntly terms this act of censorship a "piece of official stupidity" $(1998,202) .^{3}$ The novel fell prey to the Censorship Board due to a sentence which subtly invokes a homosexual relationship: "She saw Etienne and her father, in the embrace of love" $(1941 / 2006,165)$. In what sounds rather like an affectionate moment between two people in love, Kate O'Brien entirely avoids any direct reference to sexuality, let alone male homosexuality. Her main protagonist, Mother Marie-Helene, Reverend

Joyce's only experience of censorship. Dubliners, his early volume of short stories, was also a hot potato at the time. Censorious English publishers who feared prosecution for the alleged obscenity kept the book from being published for eight years. It was accepted by the London publisher Grant Richards in October 1906, but it was not until 1914 that it was published.

Kate O'Brien and Edna O'Brien are not related.

In An Age of Innocence; Irish Culture 1930-1960, Fallon uses the terms "stupid" and "stupidity" rather often when referring to the decisions of the members of the censorship board. However, he offers a quite radical revisionist reassessment of the three decades in Irish cultural history. Using a comparative analysis, that is, observing Ireland against the background of other European countries, he re-examines some widely accepted academic assumptions about this period. On the influence of the Catholic Church and the effects of the literary censorship, see Fallon, chapters 14 and 15 (1998, 183-210) 
Mother to the convent school, is after a few decades of inner torment finally able to reconstruct her past, that is, a moment in which she realized that her widowed father was gay. The euphemism itself indicates that it is rather indirect regarding sexuality. Since one of her previous novels, Mary Lavelle (1936), had already been banned, the use of the highly euphemistic phrase might be even seen as an act of self-censorship. Mary Breen points out that the sentence is "psychologically credible, whether it is the young sexually innocent construction of the adolescent who witnesses the scene, or the celibate nun's reconstruction of the traumatic event from memory" $(1993,171)$. It is therefore hard to believe that it provoked such a tremendous moral outrage in Ireland. A reviewer in the Irish Independent found the sentence "so repulsive that the book should not be left where it would fall in the hands of very young people" (Brown 1981/1985, 196).

However, the book reflects Kate O'Brien's huge disappointment with the official state policy and Ireland's neutrality in the Second World War. ${ }^{4}$ Breen argues that this novel indeed presented "a subtle threat to the narrow and xenophobic politics that ruled Ireland in the 1940s" on many various levels, and that this fact might have been the real reason behind its banning. According to her, the novel

questions and criticizes the whole ideology of that period in Irish cultural history ... by its detachment from Irish nationalism, its emphasis on individual freedom and responsibility, its championing of religious and educational structures, detached from parochial concerns, its foregrounding of the viability of female identity outside patriarchal family units, and its determinedly outward-looking European perspective. (1993, 168-9)

Already living outside Ireland (in London), O’Brien was physically and spiritually detached from her native country. This fact enabled her to imaginatively subvert what she saw as deeply wrong in the dominant state and religious ideology in Ireland of the period but also to offer her own image of Catholicism almost completely disengaged from any notion of Irish Catholicism. Interestingly enough, she decided to have an English heroine, someone with an inverted perspective on Irish life. Her English Reverend Mother simply fails to comprehend the constricted Irish view of Catholic faith, and feels awkward and out-of-place in the country she considers only in terms of "Irish exile" (1941/2006, 55). What is more, the convent of French provenance placed in the middle of Ireland is branded "too European for present-day Irish requirements" (1941/2006, 220). Represented as a somewhat different type of a religious woman, one with much more tolerant views of Catholicism than those of her Irish colleagues, Mere Marie-Helene simply encapsulates O'Brien's ideal version of Catholicism. It is also the idealized image of the convent school embodied in La Compagnie de la Sainte Famille that perforce subverts the then educational system whose aim was only to "train girls in nationalism and the Irish language, not train them to develop their talents and widen their horizons" (Weekes Owens 1990, 123). In both the character of Mere Marie-Helene and the school, Kate O'Brien obviously offers a completely idealized alternative to the unyielding religious ideology in the initial years of the Irish Free State. As Eibhear Walshe suggests, "this invented version of Catholicism is used to strike against the Ireland that censored her" $(2006,86)$.

However, The Land of Spices was un-banned five years later, in 1946, which was not the case with the novel Mary Lavelle. This novel remained blacklisted for a much longer period of time. ${ }^{5}$ Kate O'Brien's eponymous heroine, a beautiful young woman, falls in love with a married man

The novel takes place in the initial decade of the twentieth century, between 1904 and 1914 .

In the period between Mary Lavelle and The Land of Spices O'Brien wrote Pray for the Wanderer (1938), a novel which critics agree to belong to one of her least successful works. 
in Spain, where she works as a governess. She realizes that the strict order and supervisory eye of her traditionalist home country (Ireland) are exactly what she needs to prevent her from falling deeper into what she sees as a moral abyss. Although away from home and seemingly free from the suffocating concerns of life in a small rural community, Mary is, in Athusserian terms, "interpellated" or hailed by the controlling forces of state, religion and family: "Ah God, to be back there, back in her own quiet heart, in coldness and tenderness" (1936/2006, 208). Once she has freedom to decide on her own what course her life would and might take, she is, quite expectedly, at a loss as to know how to behave. She decides, however, to get involved in an illicit love affair and thus goes along with her passion in the face of the severe punishment for transgressing morally accepted behaviour. What especially irritated the censors of the day was that Mary is not just a passive girl lured into an adulterous affair but demonstrates a sexual assertiveness which totally defies Catholic submission.

What is also of great importance here is the foreign setting of the novel. ${ }^{6}$ As most commentators agree, to place a novel in which a naive Irish girl becomes involved in a sexual relationship with a married man within the Irish setting would have outraged the Irish readership to a far greater extent. However, the decision to set the plot in a foreign country did not prevent the Irish Censorship Board from proscribing it. It has to be noted that O'Brien also introduced a lesbian character, Agatha Conlon, who falls in love with and confides in Mary Lavelle, giving the censors yet another reason to ban the novel. It is therefore not difficult to imagine why Irish readers were not allowed to have access to the novel. It simply could have given ideas about alternative ways of conduct to well-brought-up Irish girls.

Walshe suggests that Kate O'Brien's fiction was truly "radical in content - each novel a Trojan horse smuggling in forbidden topics, such as adultery, lesbianism and venereal disease through the medium of her civilised, graceful narrative" $(2006,2)$. In the light of Walshe's observation, it is perhaps somewhat odd that The Ante-Room (1934) did not fall foul of the Irish Censorship Board. The novel contains direct references to the venereal disease of the main character's brother: "Ten years ago, in 1870, he had been infected with syphilis, and for three years had spent long periods in nursing homes, until sufficiently cured to live uninterruptedly at home" (1934/2003, 18). Although Reggie Mulqueen's disease is never openly mentioned later on in the novel, and nor does it ever enter any discussion of the family member, it lurks like an object of loathing, acting as a kind of backdrop against which the main events take place. The reason, however, for escaping the claws of censorship probably lies in the fact that O'Brien set the story in the milieu of the late nineteenth-century middle-class Irish bourgeoisie, and thus managed to obfuscate the too obvious allusions to contemporary Irish society. Agnes Mulqueen, the heroine of the novel, recognizes the "law," as it were, and is too well aware of the restraints that the fixtures of both religion and family impose on her. Although deeply in love with her brother-in-law, she is never really tempted to defy authorities and transgress the moral principles of her time (and Kate O'Brien's time as well). Unlike Mary Lavelle, she remains loyal (that is, subjected) to both her family and Catholic religion, and, consequently, the Irish Censorship Board did not to proscribe the novel. As Eamon Maher argues, The Ante-Room is "the closest Ireland has come to producing a Catholic novel" (2006, 111-2).

Mary Lavelle is Kate O’Brien's first "Spanish novel.” The other one with a Spanish setting is a historical novel That Lady (1946).

Walshe claims that in this novel, Spain offered O'Brien "a way out of the dead-lock" of Ireland, and goes on to say that placing her Irish protagonists within a Spanish milieu energized her as a novelist and she returned with a new intensity to her familiar preoccupations; the formation of individual conscience, ... the cruelty of passion and the variety of sexual identity. ... Spain allowed her to transcend the limitations of her imagined Mellick by suggesting a historical link between Catholic Ireland and the humanist civilization of Catholic Europe. (2006, 59-60) 


\section{Edna O'Brien and the sixties: sex, scandalous behav- iour, and "bad girls"}

Despite this hidebound atmosphere and a fixation with purity that dominated Irish life for decades, Irish society could not totally escape the loathed external influences, especially from Great Britain and America. The greatly exaggerated emphasis on the righteousness of Irish people as the only genuine manifestations of Irish post-independence lifestyle began to wane gradually in the forties and fifties. The insular concept of life which advocated rigid adherence and subjection to the precepts of the family and church could not hold any more. Along with the growing popularity of the cinema, newspapers, magazines, radio and particularly television as newly emerging media began to offer insights into more current lifestyles and ideas. The Catholic Church was rather helpless in countering the alterations of the 1960s, which would make way for a sea change in late twentieth century Irish culture. It was during this watershed era for sexuality worldwide that the parochial climate in Ireland slowly but decisively started to change

Irish literature, of course, vividly reflected this change. Around this time, coinciding with the rise of the second wave of feminism in the sixties, Edna O'Brien published the already mentioned infamous Country Girls Trilogy. The trio of novels consisted of The Country Girls (1960), Lonely Girl (1962) and Girls in Their Married Bliss (1964). Throughout her Trilogy, Edna O'Brien traces the development of two Irish girls in contemporary Ireland: their childhood in the rural West, education in a convent school and expulsion due to inappropriate behaviour, moving to Dublin and later to London in search of a job, first loves and frustrating sexual experiences, failed marriages and extramarital affairs, and, finally, the death of one of the girls in the Epilogue, which was added in 1986. In her famous essay, "Why Irish Heroines Don't Have to be Good Any More”, O’Brien argues about the decision to have two heroines, "one who would conform to both my own and my country's view of what an Irish woman should be and one who would undermine every piece of protocol and religion and hypocrisy that there was. ... Kate was looking for love. Baba was looking for money" (1986). Subverting the stereotypical virgin/whore dichotomy that burdened the image of Irish womanhood for a long time, she portrays it ingeniously in the characters of the doleful and God-fearing Caithleen and the astringent Baba.

It is significant that the former epitomizes a woman painfully torn between traditional Catholic values and modern city life which compels females to be self-confident, assertive and sexually uninhibited. The confines and oppression of a small, patriarchal and Catholic society determine her behaviour and her destiny almost as much as they do in the world of Kate O'Brien's heroines. These women recognize only too well the constant control of state and church in postcolonial Ireland and mainly comply with it. The latter, on the other hand, represents "the other side of what it means to be good," as Edna O’Brien claims (J. Quinn 1990, 137). The gold-digging Baba continually and stubbornly resists subjecting herself to the control of the social forces and thus disengages herself from the image of an ideal woman fostered by church and state. When the girls move to Dublin, Baba's main objective of getting as much pleasure out of life as possible totally undermines the concept of Catholic self-denial and frugality: "We want to live. Drink gin. Squeeze into the front of big cars and drive up outside big hotels. We want to go places" (1987/1988, 145). Even though Baba does not altogether escape the entrapment of the suffocating Catholic culture, and even though she does not get everything she wants from life (she ends up in a loveless marriage with a man she despises, gets pregnant during a one-night stand, has a bad relationship to her daughter), she still finds a way to go about things. The fact that in the Epilogue to the Trilogy Edna O'Brien kills off one of her characters, that of Caithleen and not of Baba, demonstrates symbolically 
but unambiguously that in Irish literature, the "bad" side of Irish womanhood should prevail over the often irksome kindness of the "good girl." Far from feeling that she is "interpellated" by any authority, Baba behaves in a way that Althusser terms "wicked" $(2006,113)$.

Edna O'Brien's early pioneering fiction scandalised the conservative Irish readership by openly introducing women's sexuality to the Irish literary scene. Although censorship gradually began to relax its grip in the course of the sixties, her novels were banned because she dared to blatantly subvert the dominant Catholic ideology and the feminine ideal embodied in the asexual Virgin Mary. In the words of Eavan Boland, O'Brien's contemporary in poetry, as a young poet she was reading and writing "in a world where a woman's body was at a safe distance, was a motif and not a menace" $(1995,26)$. To inscribe the female experience, particularly that pertaining to the body and sexual desire in the context of mid-century traditionalist Ireland, was simply unheard of. Edna O'Brien thus challenged the unquestioned cultural and social norms of traditional Irish society and the authority of the up-to-that-time untouchable trio of ideological apparatuses: family, Church and State. Although the easily offended Irish morality could not put up with it and each of the books was immediately banned, as we have already seen, the more liberal readership, mostly young women, readily embraced her early fiction as "catalysts for women to exchange confidences" (O'Faolain 1996, 58). O'Brien says that she is "not the darling of the feminists" who perceive her as too preoccupied with "old-fashioned themes like love and longing" (Guppy 1984). Nevertheless, it seemed that her "sexually graphic fiction" (St. Peter 2000, 73) also symbolically foreshadowed changes that were going to sweep Ireland from the late sixties onwards.

The second wave of feminism inevitably started to influence the everyday lives of Irish women, following the emergence of a worldwide hippy movement and more liberal(ized) society. Linda Connolly and Tina O'Toole argue that "consciousness-raising brought about collective knowledge of the reality of women's lived experiences, still 'invisible' and unexplored in Irish public discourse at this time." In consequence, they say, "subjects such as reproduction and sexuality entered the political arena" $(2005,27)$. It was only in 1979 that contraception, for example, was finally legalized in Ireland. The same year is also significant for Pope John Paul II's visit to Ireland. His address to Irish women contained the Church's fixed perspective on womanhood, despite the fact that a great many global changes regarding women's rights had already taken place: "May Irish mothers, young women and girls not listen to those who tell them that working at a secular job, succeeding in a secular profession, is more important than the vocation of giving life and caring for this life as a mother" ("Apostolic Journey" 1979). The Pope's visit and his messages to the Irish have prompted many heated reactions from Irish feminists, but also imaginative literary responses from women writers ever since. A harsh critique of the Pope and his view of women is also to be found in the Epilogue to Edna O'Brien's Trilogy, written a few years after his Irish visit and twenty years after the last novel of the Trilogy, Girls in Their Married Bliss. Apart from recognizing many actual changes that had occurred in Irish society throughout this period, Baba cannot restrain herself when it comes to the dogmatic rigidity of the Catholic ideology:

Now, when Pope John Paul II travels he says what Popes have been saying since secula seculorum - "Thou shalt not sin." He's still for keeping women in bondage, sexual bondage above all, as if they weren't fucked up enough with their own organs, and whoever said that all the women enjoy all the fucking they have to do - no one, certainly not me. $(1987 / 1988,522)$

Edna O'Brien's enraged heroine simply points out the reluctance of the Pope and the Catholic Church to acknowledge the considerable progress that has been made in the area of women's 
sexuality and reproduction. Moreover, Baba's outspokenness and transgression might be said to portray what many Irish women would have liked to be but never dared to try. In creating her character, O'Brien recognizes the need for a totally different, bolder type of woman in the more secular and more global Ireland in the second half and towards the end of the twentieth century.

\section{Towards the turn of the century: (Un)Concerned with Catholic Heritage?}

Beginning in the seventies, submission to the Catholic Church and the Catholic worldview, taken for granted and unquestioned up until that time, began to wane and to be replaced by different concepts and outlooks on life. The sweeping processes of globalization and consumerism wrought the inevitable secularization of Irish society (Inglis 2008, 18). Conservative Catholic culture has gradually turned into a contemporary consumerist lifestyle similar to many other Western European cultures, even though conservative tendencies in Irish politics and legislation are certainly not entirely marginalized. ${ }^{7}$ It has to be said that Catholic practice still persists, if only symbolically, alongside the newly and easily acquired consumerist habits in the lives of most people. For most Irish Catholics, "not to marry in church, not to send their children to Catholic schools, not to celebrate First Holy communions and Confirmations, and not to have a Catholic funeral would be an anathema" (Inglis $2008,16)$. However, it is quite evident that the Irish at the turn of the century no longer feel that they have to subject themselves to the once controlling social forces. A view of the new sort of ubiquitous culture that has replaced these "old" authorities is contained in Inglis's ironic commentary. Arguing about the altered habits of the Irish, he states that "much as Irish Catholics did not see themselves as dominated and controlled, neither do contemporary Irish consumers" $(2008,21)$.

It is no wonder then that the generation of Irish women writers born in the sixties and seventies are not as concerned with the Catholic and the national heritage as their predecessors were. Their fiction seems rather unburdened by the legacy of religious, cultural and literary tradition and is situated in a wider and more universal context. Following the gradual decline of the Church's monopoly and normative discourse that once heavily defined Irish womanhood, many of them have redirected their literary "targets." Irish writer Dermot Bolger's comment on the change of subjects Irish novelists have dealt with from the sixties onward, encapsulates well this problematic:

Growing up in Ireland in the 1960s, it was like you had these huge puppets of oppression, or alleged repression, to whom you could take a baseball ball and smash them. There's a new generation for whom De Valera or John Charles McQuaid mean nothing - their shadows don't stretch that far - and that's great. But their targets are far less obvious than mine were. (Maher 2006, 107)

In this respect, it might even be argued that contemporary Irish writing has lost some of its "authentic Irishness." As Gerry Smyth suggests, "Irish novelists no longer feel constrained to locate their work in terms of self-conscious 'Irish' concerns." He goes on to suggest that writers "deal instead with a broad spectrum of human experience, and with themes which, perhaps possessing local significance, also have a wider resonance" $(1997,47)$. As if going along with this argument, Eugene O'Brien points out that "no longer relegated to a sub-genre of Anglo-Irish writing, Irish writing has now assumed central stage." The corollary of this process, he contends, is that "Irish writing, while still occupied with Irish themes, has assumed a more Eurocentric perspective, looking towards European and world literature to provide images, analogues and a broader outlook on these themes" (Peach 2004, 19).

The abortion issue remains a sort of a "hot potato" and a recurrent subject of numerous public debates. 
Without fear of being censored anymore, Irish women authors of the younger generation attempt to answer the nagging question of what it means to be a woman, heterosexual or homosexual, in the hugely changed Irish society. In dealing with modern existence in Ireland, contemporary authors still tackle the issues of national and Catholic identities, but not to the extent their predecessors dealt with them. In this way, they often relegate these issues to the margins of their experience. Moreover, when contemporary women writers refer to the issues of the Catholic faith, they deal with it in a rather mocking manner and often demonstrate a great deal of irreverence. In this respect, they can be truly considered Edna O'Brien's literary successors. When O'Brien undermines Catholicism, it is mainly through Baba Brennan, who impertinently laughs at the authority of the Church. However, especially in the Epilogue, Baba is also livid at the Catholic worldview and the way church doctrine and mores contain women and women's sexuality. Edna O'Brien explains that it was "a sort of rebelliousness in me ... a scream of a kind, against my society" (Claffey 1988). Younger authors at the turn of the century apparently have no need to rail against their society, and this notion of rage is no longer present in their novels, but they still do have a need to subvert it.

In Emer Martin's novel More Bread or I'll Appear (2000), the author conveys a totally dysfunctional Irish family: an overprotective mother, five children scattered around the world, and an uncle priest in America. These motifs typical for the traditional Irish experience exist in this book only to get completely subverted and represented in the light of the changed existence at the turn of the century. She also addresses issues such as anorexia, obsessive-compulsive disorders, teenage pregnancy, incest, and AIDS, and conveys a postmodern world where every notion of stability is shattered and traditional values have disappeared or turned twisted, sick and degenerate. Particularly through the caricatured character of the hedonist gay priest Martin laughs at the doctrines of the Catholic ideology. Uncle Oscar blatantly disrupts the traditional image of a priest, and Martin seems to ascribe to him all those moral flaws discovered in the ranks of Catholic priests over the past few decades. Oscar's outrageous behaviour (alcoholism, drug use, homosexual relationships, hedonism, paedophile and incestuous tendencies) continually runs through the novel as a leitmotif against the background of the seemingly respectable position of a priest figure in American/Irish society and in the Irish family. She clearly demonstrates that after all kinds of scandals in the Church at the end of the twentieth century, Catholic priests are the very last people to be trusted.

In Martin's novel, it is not only uncle Oscar who both amuses and confuses the reader with his often exaggerated numerous addictions, twisted obsessions and sexual escapades with partners of both sexes. As a priest behaving in such a way he of course defies every notion of the traditional and profanizes the sacred in a much more extreme way than any other character in the book. Nevertheless, Martin's other characters, Oscar's nieces and a nephew who travel around the world in the course of the novel, also contribute to constructing a postmodern world where nothing seems to sit comfortably. The world of Martin's novel is totally free of any authority figure, as her characters do not feel that they are 'interpellated' by any repressive social force at any moment. If a Catholic priest is not in any way restrained, then it is quite unsurprising that other "lay" characters do not flinch from getting involved in all kinds of weird and carefree mostly sexual relationships and situations. When Fintan O'Toole says that in contemporary Irish fiction, sex, drugs and rock 'n' roll have replaced "the old Irish totems of Land, Nationality and Catholicism" (Smyth 1997, 18), it seems as if he had, particularly, Emer Martin's frenzied fictional world in mind.

The hidden, unspoken, marginal, unheard of and untoward issues that mostly pertain to sexuality thus finally find their legitimate place in the works of contemporary female authors. Gerry Smyth claims that much of the fiction 
produced in and about modern Ireland can be analysed in terms of its engagement with the social and individual fall-out from the gender division imposed by the post-colonial state, and the gradual (re)introduction of sexual desire as one of the fundamental aspects of modern Irish identity. $(1997,56)$

How sexual desire has been gradually (re)introduced to contemporary Irish fiction is best seen in the works of a proclaimed lesbian author, Emma Donoghue. Her fiction voices homosexuality, a virtually impossible practice in the literature of previous periods hampered by censorship, as we have seen in the case of Kate O'Brien. ${ }^{8}$ Donoghue's novels are notoriously populated with lesbian characters. Apart from challenging "the 'brainwashed with heterosexuality' traditional Irish culture," they also attempt "openly to explore topics of homosexual experience in an Irish context" (Jeffers 2002, 11). In her 1995 novel Hood, Pen, the main protagonist, is compelled to mourn the death of her long-time girlfriend furtively, as the society in which she is so deeply grounded would most probably stigmatize her if she did it in public. Despite the implementation of the more liberal homosexual laws ${ }^{9}$ and a sea-change that Ireland underwent in the eighties and nineties, Pen does not want to come out of the closet. There is a notion that Donoghue wants to problematize her heroine's predicament further, as she situates her in the middle of a Catholic school as a teacher and thus necessarily links her to traditional Irish culture. Pen is thus not only faced with the most probably negative reaction of her friends and family if she revealed to them the truth about her deceased "housemate" but also with the Catholic Church's unforgiving stance on homosexuality. Surrounded by nuns on a daily basis, she is too well aware of the fact that she should not risk her job by telling them the truth. It is no surprise that Pen is still intimidated by nuns and the authority of the Catholic Church just like generations of women before her. Pen cannot escape their control and authority, feeling out of place most of the time. The doors to the head nun's office always reduces her feeling like she is "twelve years old" $(1995,36)$ and whenever she enters the staff room, she "felt a thrill of taboo, as if I were still a pupil, forbidden to enter" $(1995,175)$.

However, this does not prevent the main protagonist from continually undermining the Church, its sacred symbolism and its rituals. One of the most prominent features of Donoghue's novel is the way it humorously challenges traditional Irish culture. As Antoinette Quinn says, this novel is "rarely a sombre narrative." "Irony and ridicule," she continues, are "Pen's defences against a public display of emotion, a strategy for not outing Cara posthumously by casting herself as the grieving widow" (Harte and Parker 2000, 156). I would add that irony and ridicule also imbue flashbacks into her past and the sexual reveries about her dead girlfriend which are scattered throughout the novel. Pen just cannot help questioning Catholic doctrine and observing it with a lot of healthy humour and common sense. During the memorial service for Cara, she keeps drifting off in daydreams and muses about the stern church building facilitating sexual daydreams and thoughts of masturbation. This obvious discrepancy between the setting and the state of Pen's mind is only one in the string of many moments which blatantly profanise the sacred, so to speak. Pen's sexual fantasies, vivid descriptions of masturbation and love making with Cara are certainly the most controversial parts of this book that still manage to defy Irish Catholic morality at the turn of the century.

Anne Enright's novel What Are You Like? (2000) does not exactly share the subversiveness and mockery towards traditional Irish culture of these two novels. Enright argues straightforwardly that "the Catholic Church used to enrage me, but doesn't any more. It's been well and thoroughly

Emma Donghue is considered a diasporic Irish (Irish-Canadian) author since she lives in Canada with her partner and children. The fact remains that writing lesbian fiction is perhaps easier and less problematic outside Ireland, which is still struggling to come to terms with the voicing of other sexualities.

9 Homosexuality in Ireland was officially decriminalised in 1993. 
dismantled" (Moloney and Thompson 2003, 59). This novel seems to sustain her argument as it contains very few disconnected references to Catholicism. However, Enright, too, seems unable to disengage completely from her Catholic heritage. Her narration constantly shuttles backwards and forwards, delving into the childhood of the twin girls separated at birth, Maria and Rose, then returning to the present moment, the mid-eighties. When dealing with Maria's childhood, one of the central experiences Enright focuses on is the preparation for the First Communion, probably the most important day of every Irish child's Catholic education. The way this episode is represented reveals subtle humour and even an affectionate attitude towards the whole experience. Enright's first communicant is a typical Irish girl who stands in awe of Church authorities, and this whole ritual just as it would be for any other Irish girl. She is both proud of participating in it, her soul being "white after confession, and light as an ad for margarine" $(2000,28)$, and afraid that she will be unable to receive her First Communion the way nuns have taught them to.

When Enright's narration switches to the present moment, however, Catholicism assumes totally different qualities from those it had in the past. As if wanting to distinguish between the ways her protagonists experience religion as children and as grown-up women, Enright now conveys the image directly connected with new consumer practices. Rose, a twin sister who lives in London, decides to fly to Dublin and look for her biological mother. Before her flight she enters a Heathrow chapel. The only episode in the twins' adult life that deals with Catholicism offers an image of the inside of the "church" that is almost totally disengaged from any notion of the sacred. Rose acts here as a disinterested tourist-like observer. She does not enter the chapel because she feels a need to pray but because she is drawn by the almost secular appearance of the chapel (a "bunker" reminding her of "a nightclub" $(2000,217))$. It is not surprising that Enright employs the image of a non-believer and of a consumer church replica offering quick spiritual comfort between flights in order to convey her relationship to Catholicism. Whereas Donoghue and Martin demonstrate that they are in various ways still concerned with Catholicism and tend to laugh at it, Enright seems largely unbothered and even uninterested in disrupting the Church's authority.

\section{Conclusion}

It can be argued that Kate O'Brien's critique of the Church in the thirties and forties is subtly subversive. Her women mainly subject themselves to the controlling authorities of church, state and family. The eponymous heroine of Mary Lavelle makes a conscious decision to become a transgressor, but in the end she herself forestalls the stigmatization and punishment of the intolerant Irish society by intentionally withdrawing from that same society and going into self-imposed exile. It is somewhat of a paradox, however, that Kate O'Brien makes the severest critique of these social forces through the character of the Catholic nun in The Land of Spices who should herself obey and not question religious doctrine. Edna O'Brien's debut novels, on the other hand, are already unspeakably explicit and, for the time of the sixties, greatly irreverent towards Catholicism. She situates her criticism somewhere between the nagging submissiveness of a rather typical mid-century Irish woman (Caithleen) and the defiant straightforwardness of the new type of woman (Baba). While contemporary society demands a new, much bolder and more assertive type of woman, Caithleen is, throughout her adult life, stuck in the image of an inexperienced Irish virgin and is unable to escape her predicament. The embodiment of her "dark side," Baba is quite simply Edna O'Brien's blatant response to the decades of Irish society's strict moral prescriptions. She is also the predecessor of more assertive and straightforward female protagonists in contemporary Irish fiction. As Declan Kiberd states when commenting on the importance of her Trilogy, "O'Brien was arguably the writer who made many of the subsequent advances in Irish women's writing possible" $(1995,556)$. 
Finally, the influence of Catholicism is less apparent in the works of younger authors such as Emma Donoghue, Anne Enright and Emer Martin. In contemporary Ireland which some claim to have turned post-Catholic, preoccupations with the once dominant religious ideology are certainly not in the foreground any more. It is then quite obvious that younger Irish authors are not as nearly concerned with their Catholic heritage as their predecessors were. When they write about it, however, they mostly keep mocking the Catholic Church and authorities in general. It also comes as no surprise that, unlike Edna O'Brien's Caithleen or Kate O'Brien's women, the central female protagonists in these novels do not exclusively define themselves in terms of their religion/nationality but rather explore other aspects of their identity. Emma Donoghue portrays the dominant atmosphere in Ireland in the mid-nineties, when she started to write:

It is a time of transition and confusingly rapid change, a time in which it has been immensely exciting to be out as an Irish lesbian writer. Reactions have varied from great warmth, through naïve surprise, to pulpit-thumping (my sister went to Mass the day after I appeared on television, and heard me denounced from the altar as a danger in this time of AIDS). (Tarien Powell 2004, 110)

Irish Society, which was at the time still undergoing tremendous changes, was simply at a loss to know how to tackle the fiction of the young author, who was not only unashamed but also proud of her "deviant" sexual orientation. What is significant about this quotation, however, is Donoghue's affirmative view on acting out as an Irish lesbian writer at the end of the twentieth century. She seems to acknowledge the fact that, despite the Catholic Church's uncompromising stance on homosexuality, coming out of a closet as a gay woman is not as outrageous as it used to be. Although pulpit-thumping might be still present in Irish society, it is nowadays a marginalized phenomenon as the weakened power and monopoly of the religious ideology is fortunately no longer able to proscribe and punish "disobedient" Irish writers.

\section{References}

Althusser, Louis. 2006. "Ideology and Ideological State Apparatuses (Notes Towards an Investigation).” Lenin and Philosophy and Other Essays. Translated by Ben Brewster. Delhi: Aakar Books, 85-126.

“Apostolic Journey to Ireland; Holy Mass in Limerick; Homily of the Holy Father John Paul II." 1979. Greenpark Racecource Limerick. Monday, 1 October. Accessed June 5, 2009. http://www.vatican.va/holy_ father/john_paul_ii/homilies/1979/documents/hf_jp-ii_hom_19791001_irlanda-limerick_en.html.

Boland, Eavan. 1995. Object Lessons, The Life of the Woman and the Poet in Our Time. New York, London: W. W. Norton \& Company.

Breen, Mary. 1993. "Something Understood? Kate O’Brien and The Land of Spices.” In Ordinary People Dancing, edited by Eilbhear Walshe, 167-89. Cork: Cork University Press.

Brown, Terence. 1985 (1981). Ireland, A Social and Cultural History 1922-1985. 1981. London: Fontana Press.

Cairns, David, and Shaun Richards. 1988. Writing Ireland: Colonialism, Nationalism and Culture. Manchester: Manchester University Press.

Carlson, Julia. 1990. Banned in Ireland. London: Routledge.

Claffey, Charles E. 1988. “The Vision of Edna O’Brien: Ireland's Best Known Woman Writer Brings Religious Sensibility to Her Art." The Boston Globe. New York Times Company NY, NJ, DC, MA, TX\&Intl Adresses. HighBeam Research. Accessed June 22, 2009. http://www.highbeam.com.

Connolly, Linda, and Tina O’Toole, eds. 2005. Documenting Irish Feminisms; The Second Wave. Dublin: The Woodfield Press. 
Donoghue, Emma. 1995. Hood. New York: Harper Collins Publishers.

Enright, Anne. 2000. What Are You Like. London: Jonathan Cape.

Fallon, Brian. 1998. An Age of Innocence; Irish Culture 1930-1960. Dublin: Gill and McMillan.

Fuller, Louise. 2004 (2002). Irish Catholicism Since 1950; The Undoing of a Culture. Dublin: Gill\&McMillan.

Guppy, Shusha. 1984. “Edna O’Brien, The Art of Fiction No 82.” The Paris Review. Interviews. Accessed November 21, 2010. http://www.theparisreview.org/interviews/2978/the-art-of-fiction-no-82-edna-obrien.

Howes, Marjorie. 2002. “Public Discourse, Private Reflection, 1916-70.” In The Field Day Anthology of Irish Writing; Irish Women's Writing and Traditions, Vol IV, edited by Angela Bourke et al., 923-1038. Cork: Cork University Press.

Inglis, Tom. 2008. Global Ireland, Same Difference. New York, Oxon: Routledge.

Jeffers, Jennifer M. 2002. The Irish Novel at the End of the Twentieth Century. Gender, Bodies, and Power. New York: Palgrave.

Kiberd, Declan. 1995. Inventing Ireland. London: Jonathan Cape.

Maher, Eamom. 2006. "Representations of Catholicism in the Twentieth Century Irish Novel." In Irish and Catholic? Towards an Understanding of Identity, edited by Louise Fuller, John Littleton and Eamon Maher, 103-19. Dublin: The Columba Press.

Moloney, Caitriona, and Helen Thompson, eds. 2003. Irish Women Speak Out, Voices from the Field. Syracuse, New York: Syracuse University Press.

O’Brien, Edna. 1988 (1987). The Country Girls Trilogy and Epilogue. 1987. London: Penguin Books.

_ _ _ 1986. "Why Irish Heroines Don't Have to be Good Any More." The New York Times on the Web. May 11, 1986. Accessed June 20, 2009. http://www.nytimes.com/books/00/04/09/specials/obrien-heroines.html

O’Brien, Kate. 2003 (1934). The Ante-Room. London: Virago.

_ _ _ . The Land of Spice. 2006 (1941). London: Virago.

_ _ _. Mary Lavelle. 2006 (1936). London: Virago.

O'Faolain, Nuala. 1996. Are You Somebody; The Accidental Memoir of a Dublin Woman. New York: Henry Holt and Company.

Peach, Linden. 2004. The Contemporary Irish Novel; Critical Readings. New York: Palgrave Macmillan.

Quinn, John, ed. 1990 (1986). A Portrait of the Artist as a Young Girl. London, Dublin: A Mandarin Paperback in association with Radio Telefis Eireann.

Quinn, Antoinette. 2000. “New Noises from the Woodshed: The Novels of Emma Donoghue.” In Contemporary Irish Fiction: Themes, Tropes, Theories, edited by Liam Harte and Michael Parker, 145-67. London; Macmillan Press Ltd. New York: St Martin’s Press,

Smyth, Gerry. 1997. The Novel and the Nation; Studies in the New Irish Fiction. London, Chicago: Pluto Press.

St. Peter, Christine. 2000. Changing Ireland, Strategies in Contemporary Women's Fiction. London, New York: Macmillan Press Ltd, St Martin's Press.

Tarien Powell, Kersti. 2004. Irish Fiction: An Introduction. New York, London: Continuum.

Walshe, Enda. 2006. Kate O'Brien, A Writing Life. Dublin; Portland, Oregon: Irish Academic Press.

Weekes Owens, Anna. 1990. Irish Women Writers: An Uncharted Tradition. Lexington, Kentucky: The University Press of Kentucky. 